Table 1

\begin{tabular}{|c|c|c|c|c|}
\hline & $\begin{array}{c}\text { All } \\
\text { patients }\end{array}$ & $\begin{array}{l}\text { Only those with sus- } \\
\text { pected autoimmune or } \\
\text { chronic inflammatory } \\
\text { disease in referral note }\end{array}$ & $\begin{array}{l}\text { Patients referred for other } \\
\text { reasons (fibromyalgia, } \\
\text { arthralgia, myalgia, } \\
\text { osteoporosis, etc.) }\end{array}$ & p \\
\hline Number (\%) & $136(100)$ & 71 (52.2) & $65(47.8)$ & NA \\
\hline $\begin{array}{l}\text { Age, mean years } \\
\text { (SD) }\end{array}$ & $51.8(16.3)$ & $50.7(16.4)$ & $53.1(16.2)$ & NS \\
\hline Men, n (\%) & 24 (17.6) & $15(21.1)$ & $9(13.8)$ & NS \\
\hline $\begin{array}{l}\text { Time between } \\
\text { referral and } \\
\text { triage, median } \\
\text { days (IQR) } \\
\text { Triage resolution }\end{array}$ & $\begin{array}{c}46.5 \\
(23-140)\end{array}$ & $34(15.5-124.5)$ & $54(28-441)$ & 0,017 \\
\hline $\begin{array}{l}\text { Urgent control, } \\
\mathrm{n}(\%)\end{array}$ & $92(67.6)$ & $55(77.5)$ & 37 (56.9) & 0,011 \\
\hline $\begin{array}{l}\text { Normal Control, } \\
\mathrm{n}(\%)\end{array}$ & $25(18.4)$ & $12(16.9)$ & $13(20)$ & NS \\
\hline $\begin{array}{l}\text { Primary care } \\
\text { coordination, } \\
\mathrm{n}(\%)\end{array}$ & $19(14)$ & $4(5.6)$ & $15(23.1)$ & 0,003 \\
\hline $\begin{array}{l}\text { Time between } \\
\text { triage and first } \\
\text { control, median } \\
\text { days (IQR) }\end{array}$ & $21(14-42)$ & $21(12.5-41)$ & $26(21-42)$ & NS \\
\hline $\begin{array}{l}\text { First control res- } \\
\text { olution, } \mathrm{n}(\%)\end{array}$ & $96(70.6)$ & $54(76.1)$ & $42(64.6)$ & NS \\
\hline $\begin{array}{l}\text { Diagnosis confir- } \\
\text { mation, } \mathrm{n}(\%)\end{array}$ & 37 (38.5) & $26(48.1)$ & $11(16.9)$ & 0,028 \\
\hline $\begin{array}{l}\text { Continue control, } \\
\mathrm{n}(\%)\end{array}$ & , 41 (42.7) & $26(48.1)$ & $15(23.1)$ & NS \\
\hline $\begin{array}{l}\text { Discharge to } \\
\text { primary care, } \\
\mathrm{n}(\%)\end{array}$ & $18(18.8)$ & $2(3.7)$ & $16(24.6)$ & $<0,001$ \\
\hline
\end{tabular}

SD: standard deviation; $n$ : number; IQR: Interquartile range

Conclusion: We consider this strategy as successful in reducing care times and identifying patients who require an early start of treatment and close control. Referral notes from primary care were generally adequate to identify patients who required to continue rheumatologist control.

References: None.

Disclosure of Interests: Sebastian Ibáñez Consultant of: Novartis, Paid instructor for: Bristol Myers, Speakers bureau: Abbvie, Francisca Valenzuela: None declared, Oriela Martinez: None declared, Omar Valenzuela Consultant of: Bristol Myers, Paid instructor for: Bristol Myers, Speakers bureau: Bristol Myers, Abbvie, Francisco Silva Consultant of: Roche, Speakers bureau: Roche, María José Villar: None declared, María Paz Poblete: None declared, Claudia Mardones: None declared

DOI: 10.1136/annrheumdis-2020-eular.4905

\section{THU0560 PRIMARY CARE PHYSICIAN PERSPECTIVES ON DELAYS IN DIAGNOSIS OF AXIAL SPONDYLOARTHRITIS: A QUALITATIVE STUDY}

S. H. Liu' ${ }^{1}$ K. Lapane ${ }^{1}$, D. Shridharmurthy ${ }^{1}$, S. Khan ${ }^{1}$, K. Ferrucci ${ }^{1}$, C. Dubé ${ }^{1}$, E. Yi ${ }^{2}$, J. Kay ${ }^{1,3} \cdot{ }^{1}$ University of Massachusetts Medical School, Population and Quantitative Health Sciences, Worcester, United States of America; ${ }^{2}$ Novartis Pharmaceuticals Corporation, HE\&OR and Medical Access, US Clinical Development and Medical Affairs, East Hanover, United States of America; ${ }^{3}$ University of Massachusetts Medical School, Medicine, WORCESTER, United States of America

Background: The average delay in diagnosis for patients with any form of spondyloarthritis $(\mathrm{SpA})$ ranges from 7 to 10 years [1-5]. In axial spondyloarthritis $(\operatorname{axSpA})$, a subgroup of $\mathrm{SpA}$, it is 5 to 14 years $[4,6,7]$. Factors that contribute to this delay include the lack of diagnostic criteria for axSpA and the difficulty in distinguishing inflammatory back pain (IBP), a key symptom of axSpA, from other highly prevalent forms of low back pain [8-10]. This impedes timely referral of these patients to rheumatologic care and initiation of appropriate treatment.

Objectives: Describe understanding of, attitudes towards, and practices regarding axSpA among primary care physicians.

Methods: We recruited 18 primary care physicians practicing in the United States as part of a larger qualitative study: the SpondyloArthritis Screening and Early Detection (SpA-SED) Study. We used purposive sampling with a goal of including an equal number of family medicine and internal medicine physicians who were balanced by gender. Physicians provided informed consent to participate in an in-depth interview (up to 60 minutes), conducted in person $(n=3)$ or over the phone $(n=15)$, between February and May 2019. The interview guide was developed by a multidisciplinary team, with input from rheumatologists. Topics included the physicians' approaches to evaluating back pain, their awareness about axSpA, their differential diagnosis of axSpA, the laboratory tests and imaging studies ordered when axSpA is suspected, their referral patterns for patients with presumed axSpA, their thoughts about factors contributing to diagnostic delay in axSpA, and their opinions about an Inflammatory Back Pain Assessment - ASAS criteria screening tool [5].

Results: Barriers to early diagnosis included patient factors (eg, multiple complaints, back pain not being the chief complaint), disease characteristics (eg, slow rate of disease progression), physician characteristics (eg, lack of rapport between patients and their primary care physicians), and structural/system issues (eg, lack of time). Most physicians reported that they would perform laboratory tests before referring a patient to a rheumatologist.

Conclusion: Primary care physicians were surprised to learn of the average delay to axSpA diagnosis, considered that this lengthy delay was problematic, and agreed that improvements are needed in screening for and early detection of axSpA. Physicians believed that there would be a role for using a screening tool in the primary care setting to improve diagnostic delay, but that evidence to support its implementation is needed.

References:

[1] Dougados M et al. Arthritis Rheum. 1991;34:1218-27.

[2] Amor B et al. Rev Rhum Mal Osteoartic. 1990;57:85-9.

[3] van der Linden S et al. Arthritis Rheum. 1984;27:361-8.

[4] Deodhar A et al. Arthritis Rheumatol. 2016;68:1669-76.

[5] Sieper J et al. Ann Rheum Dis. 2009;68:784-8.

[6] Sykes MP et al. Rheumatology (Oxford). 2015;54:2283-4.

[7] Redeker I et al. Rheumatology (Oxford). 2019;58:1634-8.

[8] Strand V et al. Mayo Clin Proc. 2017;92:555-64.

[9] Proft F et al. Ther Adv Musculoskelet Dis. 2018;10:129-39.

[10] Bohn R et al. Clin Exp Rheumatol. 2018;36: 263-74.

Acknowledgments: We thank the participants for sharing their insights as part of this study. This abstract was written using data from a research study originally funded by Novartis (Principal Investigator: Shao-Hsien Liu, Co-Investigators: Jonathan Kay, Kate Lapane, Catherine Dubé)

Disclosure of Interests: Shao-Hsien Liu Grant/research support from: Novartis Pharmaceuticals Corporation, Kate Lapane Grant/research support from: Novartis Pharmaceuticals Corporation, Divya Shridharmurthy Grant/research support from: Novartis Pharmaceuticals Corporation, Sara Khan Grant/ research support from: Novartis Pharmaceuticals Corporation, Katarina Ferrucci Grant/research support from: Novartis Pharmaceuticals Corporation Catherine Dubé Grant/research support from: Novartis Pharmaceuticals Corporation, Esther Yi Employee of: Novartis Pharmaceuticals Corporation, Jonathan Kay Grant/research support from: Gilead Sciences, Inc., Pfizer, Novartis Pharmaceuticals Corporation, Consultant of: Alvotech Suisse AG; Arena Pharmaceuticals, Inc.; Boehringer Ingelheim GmbH; Celltrion Healthcare Co. Ltd.; Merck Sharp \& Dohme Corp.; Mylan Inc.; Novartis AG; Samsung Bioepis; Sandoz, Inc; UCB, Inc.

DOI: 10.1136/annrheumdis-2020-eular.2004

\section{THU0561 PREDICTING LIVER TOXICITY CAUSED BY CONVENTIONAL SYNTHETIC DISEASE-MODIFYING ANTIRHEUMATIC DRUGS}

L. Kuusalo $^{1}$, M. Venäläinen ${ }^{2}$, S. Saranpää ${ }^{3}$, H. Kirjala ${ }^{3}$, L. Elo ${ }^{2}$, L. Pirilä ${ }^{1}$. ${ }^{1}$ University of Turku and Turku University Hospital, Center for Rheumatology and Clinical Immunology, Turku, Finland; ${ }^{2}$ University of Turku, Turku Bioscience Center, Turku, Finland; ${ }^{3}$ University of Turku, Turku, Finland

Background: Routine laboratory testing is recommended for early identification of toxicity during conventional synthetic disease modifying antirheumatic drug (csDMARD) treatment. Based on expert consensus, testing is recommended every 2-4 weeks for the first 3 moths and quarterly thereafter (1).

Objectives: In addition to evaluating the incidence of alanine transaminase (ALT) elevations in rheumatoid arthritis (RA) patients initiated on 1-2 csDMARDs, we aimed to distinguish patterns in ALT levels to develop a model for identifying patients at high risk for liver toxicity.

Methods: We identified RA patients who were initiated a new csDMARD course at the rheumatology clinic of Turku University Hospital in 2013-2019. Baseline and follow-up safety monitoring results were drawn from the electronic health record (EHR) data. Data on diagnoses and csDMARD initiation/cessation dates were manually confirmed from the EHR.

As the primary endpoint, we used ALT-elevations of more than twice the upper limit of reference range (women $\geq 70 \mathrm{U} / \mathrm{l}$, men $\geq 100 \mathrm{U} / \mathrm{I}$ ) within 6 months after treatment initiation. Intergroup differences were tested using Mann-Whitney test for continuous variables and the chi-square test or Fisher's exact test $(n<5)$ for categorical variables. Associations between different 